\title{
Generating of Electric Energy by a Declined Overburden Conveyor in a Continuous Surface Mine
}

\author{
Witold Kawalec*(i) and Robert Król (D) \\ Faculty of Geoengineering, Mining and Geology, Department of Mining, Wroclaw University of Science and \\ Technology, Na Grobli 15, 50-421 Wroclaw, Poland; robert.krol@pwr.edu.pl \\ * Correspondence: witold.kawalec@pwr.edu.pl
}

Citation: Kawalec, W.; Król, R. Generating of Electric Energy by a Declined Overburden Conveyor in a Continuous Surface Mine. Energies 2021, 14, 4030. https://doi.org/ $10.3390 /$ en14134030

Academic Editor: Rouhi Farajzadeh

Received: 26 May 2021

Accepted: 1 July 2021

Published: 4 July 2021

Publisher's Note: MDPI stays neutral with regard to jurisdictional claims in published maps and institutional affiliations.

Copyright: (c) 2021 by the authors. Licensee MDPI, Basel, Switzerland. This article is an open access article distributed under the terms and conditions of the Creative Commons Attribution (CC BY) license (https:// creativecommons.org/licenses/by/ $4.0 /)$.

\begin{abstract}
Exploitation of lignite in continuous surface mines requires removing masses of overburden, which are hauled to a dumpsite. There are some technological arrangements where the overburden is transported several dozen meters down to a spreader operating on a lower located dumping level. Depending on an angle of a declined transportation route, there is a possibility to convert the potential gravitational energy of conveyed down overburden masses into electric energy. To recover the maximum percentage of stored energy, an energy-effective and fully loaded belt conveyor should work in a generator mode. Due to the implementation of such a solution, a lignite continuous surface mine, which is a great electric energy consumer, can obtain the status of an electricity prosumer and reduce its environmental impact, in particular demonstrating significant savings in primary energy consumption. Though lignite surface mining is phasing out in Europe, the recuperative, overburden conveyors for downhill transport match up the targets of sustainable mining, understood as getting the maximum benefits from the exploited natural resources. According to the analyzed case study, an investment into the installation of regenerative inverters for the electric power supply of the declined overburden conveyor would pay off within 3-4 years.
\end{abstract}

Keywords: belt conveyor; prosumer; downhill transport of overburden; specific energy consumption; recuperation; energy recovery rate

\section{Introduction}

Belt conveyors are extensively used in industrial bulk material transportation worldwide. There are estimations that more than 2.5 million conveyors are in use [1,2]. Surface lignite mines are arguably the users of the largest and the most complex belt conveyor systems. The Energy Efficiency Act issued in 2016 [3], in line with the relevant directives of the European Parliament [4], imposes on such large enterprises the obligation to perform periodic energy audits, which should document the improvements introduced to reduce energy consumption, decreasing the "carbon footprint". In surface mines, one of the directions of this activity is recovering the potential gravitational energy in each case of transporting overburden downhill. Belt conveyors, driven by electric motors, can be easily converted into electricity-generating machines [5]. A flagship example of an energy recovery belt transportation is a system of innovative belt conveyors in the Los Pelambres copper ore mine in Chile. It generates up to $25 \mathrm{MW}$ power on a $13 \mathrm{~km}$ route with a decline of $1310 \mathrm{~m}$ and supplies this electric energy to the entire mine [6,7].

Articles [8,9] have introduced the concept of a potential gravitational energy deposit, which exists as an accompanying deposit in the case of a mineral location in a mountain area, from which the extracted material is transported down to a storage yard by a public road or railway siding. For an aggregate deposit with an operational resource of 5 million tons, from which the output is transported to a depot lying $200 \mathrm{~m}$ below the level of the excavation, the potential gravitational energy resource is substantial 2.7 GWh (230 toeequivalent oil, in which fossil fuel savings are counted [3]). The percentage of yield of this 
resource (a potential gravitational energy recovery) depends on the angle of declination of a conveyor route, its energy efficiency [8], and the implementation of the potential energy recovery-oriented haulage technology, consisting of avoiding its idle or low-efficiency working mode [8]. In the aggregate mines, the movement of heavy mining vehicles (exhaust gases, vibrations, destruction of roads) has a negative impact on the environment and may even prevent the exploitation of the mineral. It has been identified as a reason for the "annihilation of resources" even in barely populated areas in Norway [10]. The replacement of heavy trucks with belt conveyors allows eliminating these problems.

Unlike rock mining, belt conveyor transportation systems have always been commonly used in continuous surface lignite mines. Though these mines are mostly located on a flat area, due to their depth and specific technological arrangements, there are various possibilities to convey large amounts of overburden downhill by declined conveyors.

Continuous lignite surface mining is phasing out in Europe due to the EU climate action and the European Green Deal [11]. However, some 380 million tons of lignite is still mined annually in open cast operations [12]. Approximately 1 billion cubic meters (cbm) of overburden has to be removed annually to allow these lignite operations. Some of the overburden volumes (and masses) are conveyed downhill, which will be even more extensive during the oncoming closure works. Due to the implementation of such a solution, a lignite continuous surface mine, which is a great electric energy consumer, can obtain the status of an electricity prosumer and reduce its environmental impact (certified by so-called "white certificates" of saved energy [3]).

The efficiency of the conveyor operation in energy recuperation mode depends on the slope angle of the descending conveyor route profile and the actual capacity of the conveyor. The maximum use of the gravity of the transported material is favored by achieving low motion resistance of the main belt conveyors equipped with energy-efficient conveyor belts, rigidly mounted, energy-saving roller sets, and proper belt guidance [1]. For the conveyor transporting downwards, the balance of the component gravity force of the excavated material and aggregated resistance to motion is crucial [13]. The goal of this paper is to reveal the opportunity to mine the potential gravitational energy reserves in the lignite surface mines during their exploitation and post-closure phases.

\section{Materials and Methods}

The basis of the study originated from the complexity and variability of overburden removal conveyor systems in lignite continuous surface mines, which have to be rearranged several times over the life of a mine to keep transportation costs low [14]. In Figure 1, the schematic sections of a continuous surface mine show the three typical technological layouts of removing volumes of overburden downhill to the dumping levels.

The overburden removed from the upper overburden levels is often placed down the transportation ramp to the dumping levels on the lower elevation (Figure 1a). This configuration of the haulage route "creates" a potential gravitational energy deposit, and a declined conveyor installed on the transportation ramp can work in a regenerative mode. The differences in elevations are moderate, assuming conservatively not more than the height of 3-4 mining levels, i.e., $60-80 \mathrm{~m}$. However, the continuous surface mines are mostly large, and from each overburden level, at least a few million cbm of overburden is removed annually (with an average density of about $1700 \mathrm{~kg} / \mathrm{cbm}$ ). Therefore, this transportation arrangement "creates" a potential gravitational energy resource of $1 \mathrm{GWh}$ per year on each mining level. Although the amount of energy recovered is small in comparison to that consumed by the lignite coal mine transport system, this recovery allows obtaining the status of an energy prosumer, valuable not only due to money savings but also due to the growing importance of a corporate social responsibility [15]. 


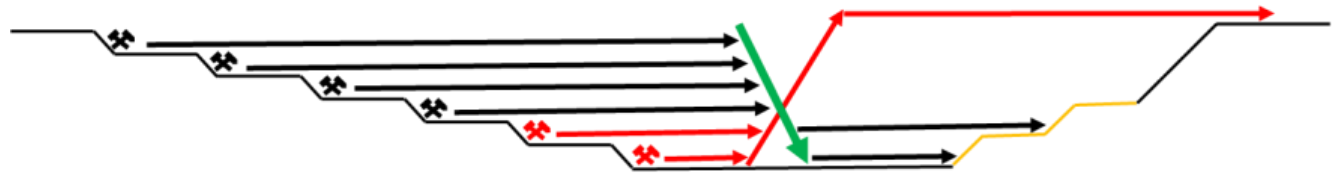

(a)

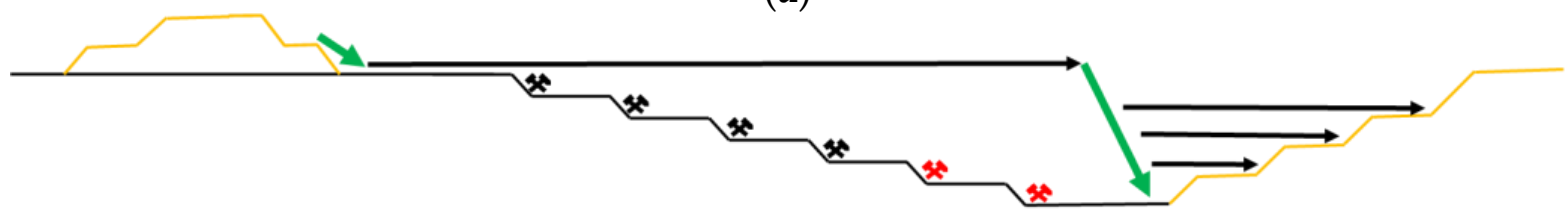

(b)

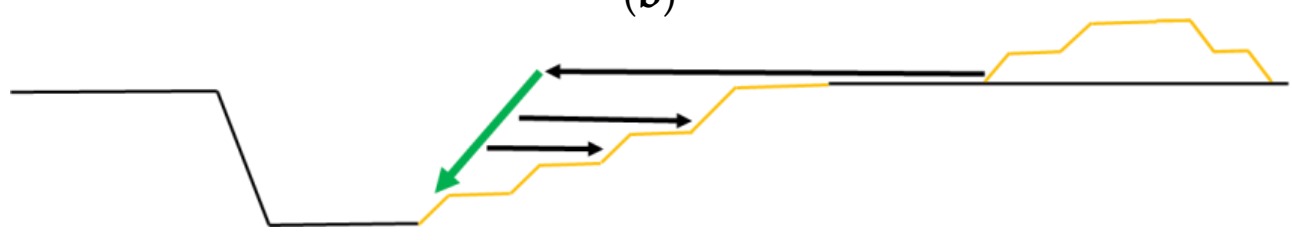

(c)

Figure 1. A schematic section through a continuous surface mine with various arrangements of overburden removal enabling the recovery of potential gravitational energy (red, black, green arrows-coal, overburden horizontal, overburden declined conveyors, respectively; yellow profile lines-dump sites, crossed hammers-exploitation levels); (a) Removing overburden volumes from mining levels to an in-pit dumping levels, (b) Translocation of overburden volumes previously temporarily dumped on a foreground to the final in-pit dumping levels, (c) partially liquidation of an external dump for the needs of reclamation earthworks of a post-mining void (shallowing and slopes forming)

Another technological arrangement suitable for electric energy recovery is the relocation of the overburden from a temporary dumpsite located on a foreground of the pit advance (Figure 1b) or from an external dump after the mine closure (Figure 1c). In both cases, there are anthropogenic potential gravitational energy deposits, which were previously built against a large amount of consumed energy. Both cases will become more feasible soon when, due to the European Green Deal policy, lignite mining will be put into the closure stage. Reclamation of the closed mining voids will require massive earthworks [16]. Then there is a possibility of a partial recovery of electricity previously used during the temporary dumping.

Therefore, after identifying the possibility for recovery of potential gravitational energy of the overburden in accordance with the excavation development plan (or relocation of the dumping ground), the conveyors can be properly configured on the distribution point (on the transportation ramp) with the installation of automatic drive control for maximum energy recuperation. Depending on the actual load, a declined conveyor works either in the mode of driving or braking the belt (generator operation). Though it brings increased design and operational difficulties [17], the development of automation, multichannel monitoring of the conveyor's operation, signaling of emerging and expected threats [18], and improved calculation methods come with the help [17,19]. Regenerative drives equipped with frequency converters for energy recovery are available to control the operation of variable load drive. During braking, energy is returned to the mains instead of being converted into heat (wasted) using braking resistors (as it is still common nowadays). The recovered energy can be returned to the network in prosumer mode or used locally, e.g., to supply electricity to other nearby installed devices.

In Polish surface lignite mines, haulage of overburden is carried out mainly with high-performance B1800 or B2250 (belt width in millimeters) conveyors with steel-cord belts running with a speed of 5.25-5.9 m/s [20]. Overburden is excavated by bucket-wheel excavators with long periods of work with stable performance (Figure 2), in accordance with the current overburden removal schedule $[20,21]$. 


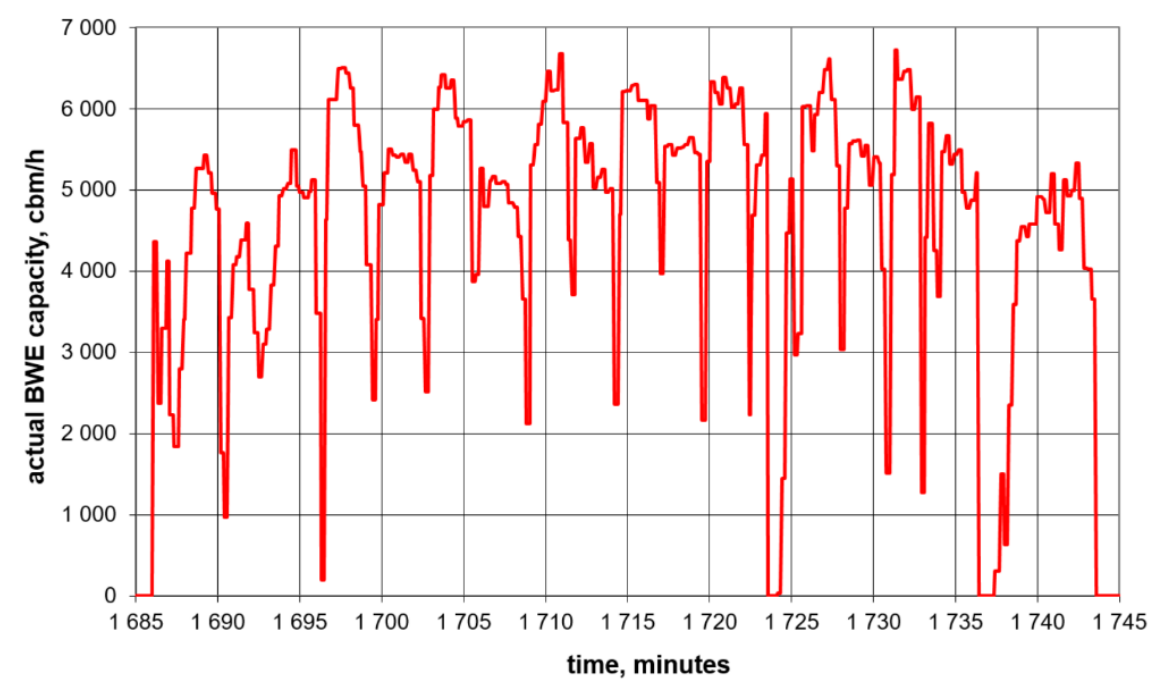

Figure 2. Actual volume capacity for the SRs 2000 bucket-wheel excavator recorded in the Belchatow surface lignite mine during the excavation of one terrace [20].

The widely adopted measure of a belt conveyor efficiency is its specific energy consumption (SEC) - an amount of energy needed to move $1 \mathrm{~kg}$ of conveyed material for a distance of $1 \mathrm{~m}$. Having obtained measurements of actual power and capacity of a belt conveyor, it can be calculated from the equation [13]:

$$
S E C=\frac{N}{\dot{M} \cdot L}\left[\frac{W \cdot S}{k g \cdot m}=\frac{N}{k g}\right]
$$

where: N-drive power, $\mathrm{W} ; \dot{M}$-actual capacity, $\mathrm{kg} / \mathrm{s} ; \mathrm{L}$-conveyor length, $\mathrm{m}$.

The drive power reflects the actual belt conveyor resistances to motion. These are divided into primary (or main) resistances that occur along the whole conveyor route, secondary (exerted at the head and tail stations-on pulleys, loading points, cleaning devices) resistance, and lift resistance. After converting (1) into the equation with resistances to the motion, we get [13]:

$$
S E C=\frac{W_{\text {main }}}{M \cdot \eta}+\frac{W_{\text {secondary }}}{M \cdot \eta}+\frac{g}{\eta} \cdot \sin \delta
$$

where: $W$-resistance to motion, $W ; M$-total mass of the transported material on a conveyor, $\mathrm{kg} ; \eta$-drive efficiency; $g=9.80665 \mathrm{~m} / \mathrm{s}^{2} ; \delta$-angle of inclination of a belt conveyor route

The total mass of the transported material on the conveyor equals:

$$
M=\frac{L \cdot \dot{M}}{v}
$$

where: $v$-conveyor belt speed, $\mathrm{m} / \mathrm{s}$

After applying (3) to (2), we get the equation of the components of specific energy consumption:

$$
\begin{aligned}
& S E C=\frac{v}{L \cdot \dot{M} \cdot \eta}\left(W_{\text {main }}+W_{\text {secondary }}\right)+\frac{g}{\eta} \cdot \sin \delta \\
& \text { or }: S E C=S E C_{\text {main }}+S E C_{\text {secondary }}+\frac{g}{\eta} \cdot \sin \delta
\end{aligned}
$$

The $S E C_{\text {main }}$ and $S E C$ secondary decrease with the rising actual capacity with regard to the actual parameters of a belt conveyor [9]. The $S E C_{\text {secondary }}$ decreases with the increasing conveyor length. The positive or negative value of the SEC depends on the actual balance of these components. The negative values represent the regenerative mode of operation. 
In order to determine the area of possible energy recuperation with the overburden conveyor, simulation calculations of motion resistances with the necessary drive power for route variants after a fall with a moderate slope of 2 to 7 degrees were performed. A route length of about $600 \mathrm{~m}$ was adopted, suitable for a conveyor working on a transportation ramp (see Figure 1). In the calculations, the specialized QNK-TT software for calculating belt conveyors' motion resistances and drive power demand was used. Unlike the simplified standard algorithms, the QNK-TT software uses the more accurate method of calculating individual components of the main resistances to motion $[17,19]$. This is done on the basis of the theoretical analysis of the energy dissipation processes in a conveyor belt and the material load stream, and the analysis of the interaction between the belt and idlers. The investigations were validated against the numerous laboratory and industrial tests $[22,23]$ and eventually resulted in verified algorithms for calculating motion resistances. In the QNK-TT program, a large set of data of a belt, transported bulk material, and the design characteristics of a conveyor, as well as its specific operating conditions, are used, and calculation results allow analyzing the impact of selected parameters on the belt conveyor drive power requirement.

The following conveyor parameters were adopted:

- Steel-cord belt B1800 ST $3150(12+7), 79.4 \mathrm{~kg} / \mathrm{m}$, belt speed: $5.9 \mathrm{~m} / \mathrm{s}$

- Idlers: upper (carry): rigidly mounted, with a troughing angle of $45^{\circ}$ and a spacing of $1.25 \mathrm{~m}$, bottom: V-type with a spacing of $3 \mathrm{~m}$; standard rotating resistance (appr. $4.5 \mathrm{~N}$ for each roller)

- Power units $(4 \times 630$ or $2 \times 800 \mathrm{~kW})$ at the tail head station, controlled by an inverter, - Belt take-up at the head station,

- Reference ambient temperature of $11^{\circ} \mathrm{C}$, low belt mistracking, good operating conditions

- Transported overburden: density $1700 \mathrm{~kg} / \mathrm{cbm}$; maximum capacity: $8800 \mathrm{cbm} / \mathrm{h}$ $(13,500 \mathrm{t} / \mathrm{h})$.

The lack of belt mistracking and good operating conditions are typical for main conveyors working on transportation ramps in large continuous lignite surface mines that are maintained by a highly professional staff. Motion resistance and drive power (positive or negative) were calculated for the adopted variants of the route inclination downward, assuming the belt tension force was fixed for the maximum load of transported material. The drive power map presents the results of the balance of power calculated at the drive pulley shaft (Figure 3).

The area of positive power (conveyor is driven) shown in Figure 3 above the level of $0 \mathrm{MW}$ indicated that the conveyor with an angle of inclination downward up to $-3^{\circ}$ is not suitable for energy recovery. Larger angles of the route inclination downward (from $-4^{\circ}$ to $-7^{\circ}$ ) allow energy recuperation in a sufficiently wide performance range, assuming that the actual conveyor capacity exceeds $10 \%$ of the maximum one. The graph above shows the isolines of calculated power values for the stabilized transported overburden stream, which is typical for overburden removal (see Figure 2). However, for uneven streams, the resistance to motion increased (up to 10\% [20]), which decreased the amount of recuperated energy. In addition, any maintenance failures (e.g., worn idlers, belt mistracking) or low ambient temperature cause an increase in the respective components of motion resistances. These factors will also reduce the capability of energy recovery.

The values of power ranges of the main drive are illustrative for the technical staff. For the needs of an assessment of the recovery rate of the potential gravitational energy of conveyed down overburden masses, the map of energy recovery is more useful (Figure 4).

In Figure 4, only the area of the energy recovery rate exceeding $10 \%$ is mapped. Such a map can be used for scheduling the overburden removal in order to keep the actual conveyor capacity within the area of a high energy recovery rate. 


\section{Drive power, MW}

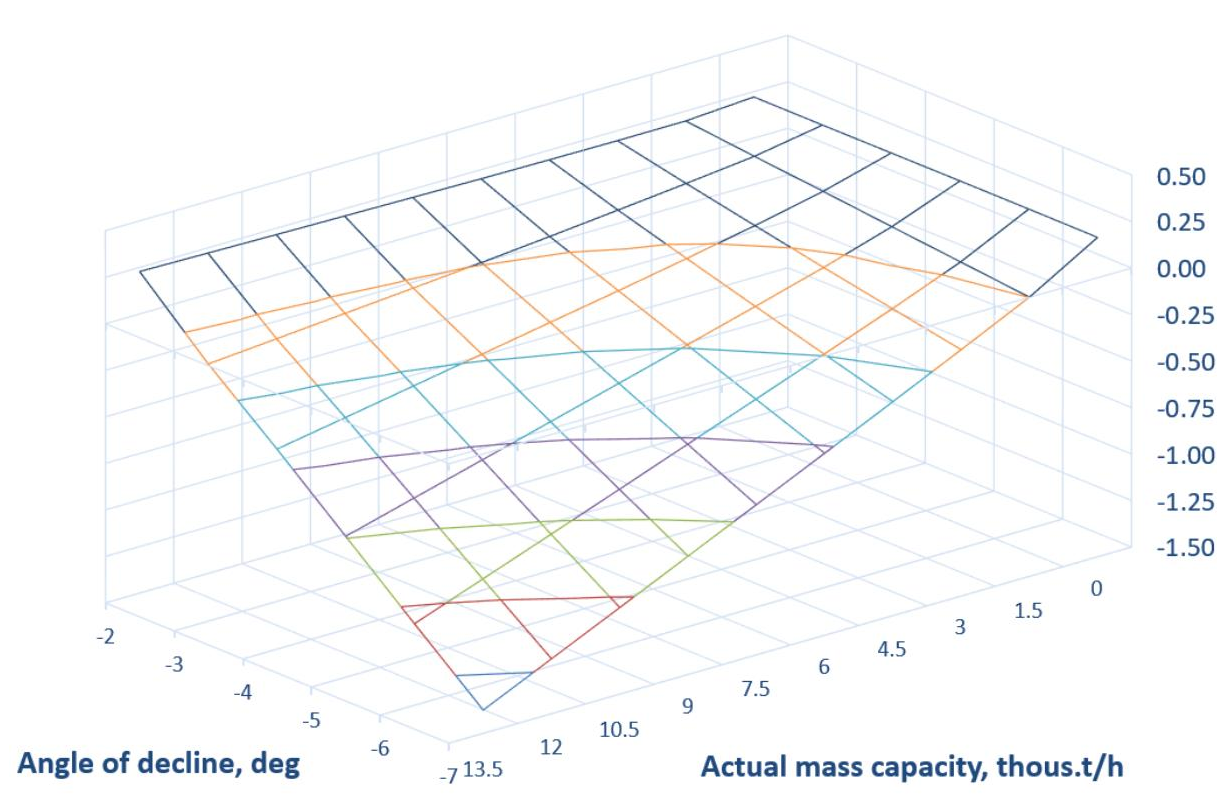

Figure 3. 3-D map of the power ranges of the main drive of the B1800 descending conveyor depending on the mass capacity and the angle of inclination downward (decline) of the conveyor route (calculations: QNK-TT).

\section{Energy recovery, \%}

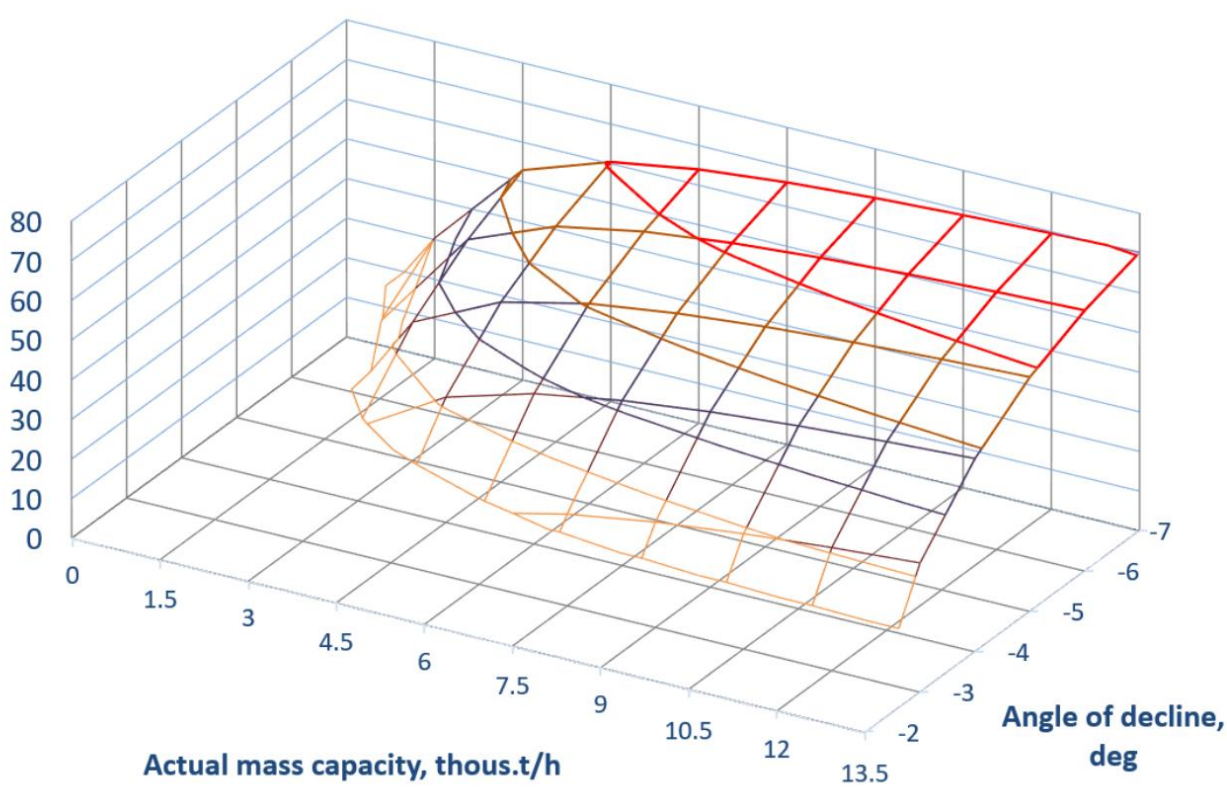

Figure 4. 3-D map of the recovery rate of the potential gravitational energy of mined overburden with the use of analyzed the B1800 descending conveyor depending on the mass capacity and the angle of inclination downward of the conveyor route (calculations: QNK-TT).

\section{Results}

The graph of positive or negative drive power of the overburden conveyor working on the transportation ramp presented in the previous point presents the general possibilities of electricity recuperation from overburden haulage. In each case, they should be estimated on the basis of specific plans for the advance of mining and dumping fields, containing the expected overburden volumes, which would be directed from the given overburden 
mining levels to the dumper operating on the lower elevation. It has to be pointed out that the overburden dumping plans are developed according to the geotechnical requirements, and the material from a given mining level can be sent to various dumping levels in order to secure the stability of the dumping slope [18]. In a large surface mine consisting of several mining and dumping levels, various configurations of dumping the overburden are used.

Assume that the collective overburden conveyor (length $565 \mathrm{~m}$, average downward slope angle $-7.2^{\circ}$ ) is fed on three successive overburden levels (marked A, B, C from the top; each mining level is $20 \mathrm{~m}$ high, the head station is positioned $70 \mathrm{~m}$ down from the top A level) by horizontal conveyors loaded with overburden directly from bucket-wheel excavator class KWK 1500 with a nominal capacity of $4200 \mathrm{cbm} / \mathrm{h}$ (see Figure 5). A, B, $\mathrm{C}$ excavators work for long periods with stable performance, according to the current disposition. The conveyor works $2000 \mathrm{~h}$ a year. Each excavator removes annually some 4 million cubic meters of overburden, which is transported to this conveyor. Excavators can work in different systems: all (but with limited capacity), two of three (with different levels of performance), or one of three. The actual working mode of the excavators and the actual capacity are not random as they are controlled from the mine control room by a shift dispatcher. Unlike the quality parameters driven by control of selective lignite mining in the case of mining the overburden benches, the dispatcher is obliged to follow the daily overburden removal schedule and maintain the overall energy efficiency of machinery and transportation equipment.

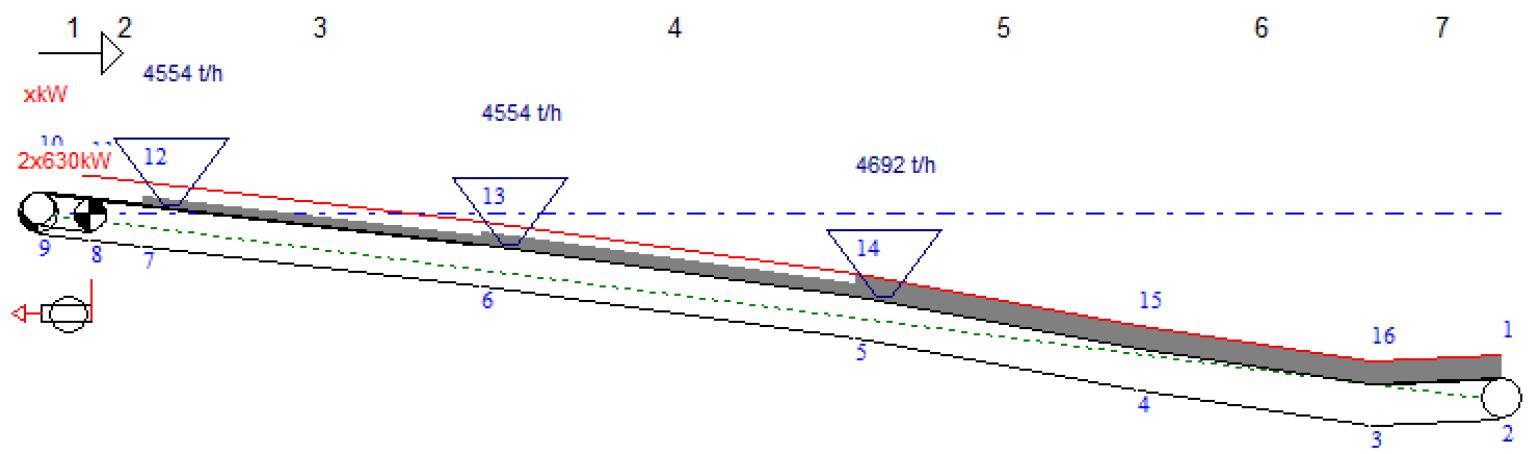

Figure 5. The profile of the study route of the overburden conveyor on the ramp, receiving overburden at three loading points on three subsequent mining levels, which is discharged at its head (source: QNK-TT).

For these assumptions, 10 modes of excavating overburden by excavators A, B, C were adopted, supplying the declined conveyor with a stabilized bulk stream controlled by the dispatcher. Modes 1-3 represent the loading by a single excavator digging at its top output, modes 4-6 and 8-10-loading by two excavators at the limited or partly limited output, while mode 7-equal loading by all three excavators (however with the limited output each). Idle or low duty work of the main conveyor is not provided. If such periods of work took place, then (according to the diagram in Figure 2) the conveyor would be driven, but then transport tasks would practically not be carried out at all. It can therefore be assumed that these would be additional hours of idle operation of the conveyor.

A hypothetical share of the working time of each of the accepted modes of work was set so as to implement the overburden removal plan. Table 1 summarizes the data on the output stream on the main, declined conveyor on the transportation ramp, and the calculated resultant drive power for each mode of operation, as well as the total annual values - the sum of the volume and mass of the overburden and the average drive power.

The declined conveyor on the transportation ramp transporting overburden from three upper mining levels to the most bottom dumping level generates approximately $790 \mathrm{~kW}$ (weighted average value against the presumed distribution of the supplied volumes). This means that it could produce nearly 1.6 GWh of "green" electricity per year (equivalent to some 140 toe) from the total $2.8 \mathrm{GWh}$ of the combined potential gravitational energy 
accumulated on the overburden mining levels A, B, and C (calculated with regard to the elevation of the conveyor discharge point at its head pulley). The average energy recovery rate reaches some $54 \%$. A similar amount of energy can be obtained from a $1 \mathrm{MW}$ windmill, whose construction cost, however, is about EUR 1 million.

Table 1. Variants of loading the analyzed conveyor on a ramp with overburden stream from three excavators A, B, C at subsequent mining levels (the conveyor is discharged at its head) and the resulting drive power.

\begin{tabular}{|c|c|c|c|c|c|c|c|c|c|c|c|}
\hline & & \multicolumn{10}{|c|}{ Mode of Loading Overburden on Levels A, B, C and Its Presumed Share of the Operation Time } \\
\hline \multirow{2}{*}{\multicolumn{2}{|c|}{$\begin{array}{l}\text { Mining Levels Supply } \\
\text { (Volumes, Tonnages) }\end{array}$}} & 1 & 2 & 3 & 4 & 5 & 6 & 7 & 8 & 9 & 10 \\
\hline & & 0.075 & 0.075 & 0.075 & 0.1 & 0.1 & 0.1 & 0.25 & 0.075 & 0.075 & 0.075 \\
\hline \multirow{2}{*}{ A } & $\mathrm{cbm} / \mathrm{h}$ & 4200 & 0 & 0 & 3000 & 4200 & 0 & 2500 & 2500 & 0 & 2500 \\
\hline & tonnes $/ \mathrm{h}$ & 7140 & 0 & 0 & 5100 & 7140 & 0 & 4250 & 4250 & 0 & 4250 \\
\hline \multirow{2}{*}{ B } & $\mathrm{cbm} / \mathrm{h}$ & 0 & 4200 & 0 & 0 & 3000 & 4200 & 2500 & 0 & 2500 & 2500 \\
\hline & tonnes $/ \mathrm{h}$ & 0 & 7140 & 0 & 0 & 5100 & 7140 & 4250 & 0 & 4250 & 4250 \\
\hline \multirow{2}{*}{$\mathrm{C}$} & $\mathrm{cbm} / \mathrm{h}$ & 0 & 0 & 4200 & 4200 & 0 & 3000 & 2500 & 2500 & 2500 & 0 \\
\hline & tonnes $/ \mathrm{h}$ & 0 & 0 & 7140 & 7140 & 0 & 5100 & 4250 & 4250 & 4250 & 0 \\
\hline \multirow{2}{*}{$A+B+C$} & $\mathrm{cbm} / \mathrm{h}$ & 4200 & 4200 & 4200 & 7200 & 7200 & 7200 & 7500 & 5000 & 5000 & 5000 \\
\hline & tonnes $/ \mathrm{h}$ & 7140 & 7140 & 7140 & 12,240 & 12,240 & 12,240 & 12,750 & 8500 & 8500 & 8500 \\
\hline \multicolumn{2}{|c|}{ Calculated drive power, $\mathrm{kW}$} & -702 & -486 & -170 & -847 & -1229 & -806 & -1048 & -586 & -485 & -788 \\
\hline \multicolumn{2}{|c|}{ potential energy recovery, \% } & 52 & 50 & 29 & 54 & 60 & 58 & 60 & 51 & 52 & 57 \\
\hline
\end{tabular}

For the listed above working modes of excavators on mining levels, very different levels of energy recovery were obtained. It should be assumed that in the "control room" of a given mine, an appropriate panel would appear with parameters of energy recovery by the conveyor (s) in recuperation mode so that the dispatcher could properly manage the work of removing the overburden.

The declined conveyor on the transportation ramp is often discharged on its route-not at its head pulley (see Figure 1) in order to supply the overburden to the selected dumping level. Can it still generate energy, then? The following table presents the hypothetical results of drive power demand for two variants of unloading the downhill conveyor: 1 or 2 mining levels below the second exploitation level (see Figure 6).

When a conveyor is discharged on its route, the moving discharge station is installed on the construction. The belt is lifted there from the top idlers and wrapped on two pulleysthe first is the discharging one, and the second puts the emptied belt on the top idlers again to let it go to the head pulley. The station creates additional resistances to motion that have to be taken into account for calculations of the drive power. Again, the hypothetical share of the working time of each of the accepted modes of work is implemented according to the possible overburden removal plan. Table 2 summarizes the results of simulating the transportation work of the conveyor, which supplies alternatively two dumping levels.

Under such arrangements, the declined conveyor generates less energy-approximately $530 \mathrm{~kW}$ (weighted average value). It equals 1.06 GWh of "green" electricity per year out of the total 2.3 GWh of the combined potential gravitational energy accumulated on the overburden mining levels A and B (calculated with regard to the actual elevation of the conveyor discharge point as showed in Figure 5). In this case, the average energy recovery rate equals $45 \%$. Each alternative arrangement of the actual loading and discharging of the downhill conveyor can be easily checked against the available energy recovery rate. These calculations should be taken into consideration for the energy recuperating oriented planning of dumping operations. Overburden is often scattered by a spreader positioned on the upper dumping level (higher than necessary), and the dumped material falls from a big height onto the ground. It causes both the loss of the potential gravitational energy and also excessive dust contamination of the dumped material. 


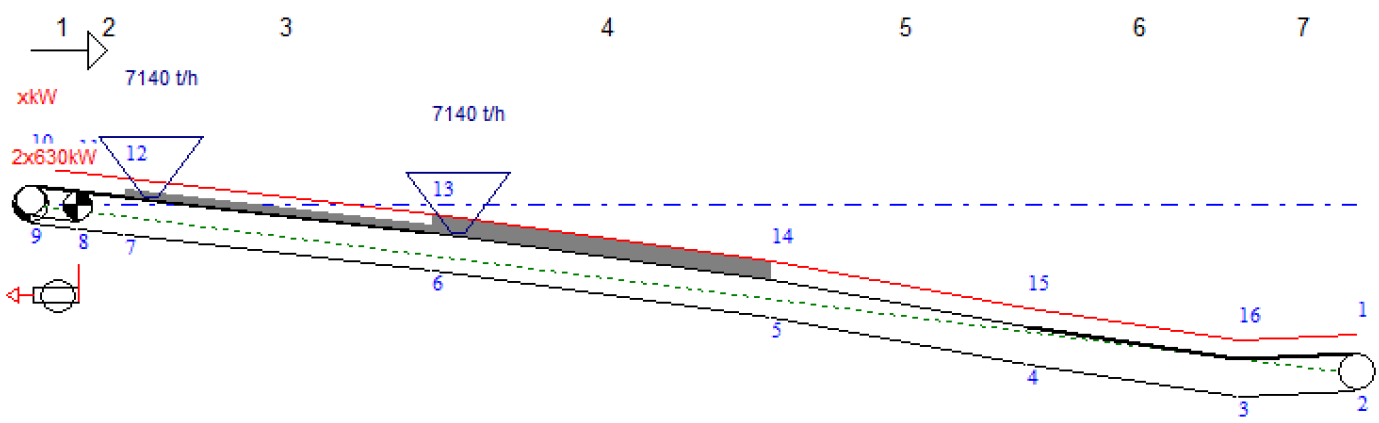

(a)

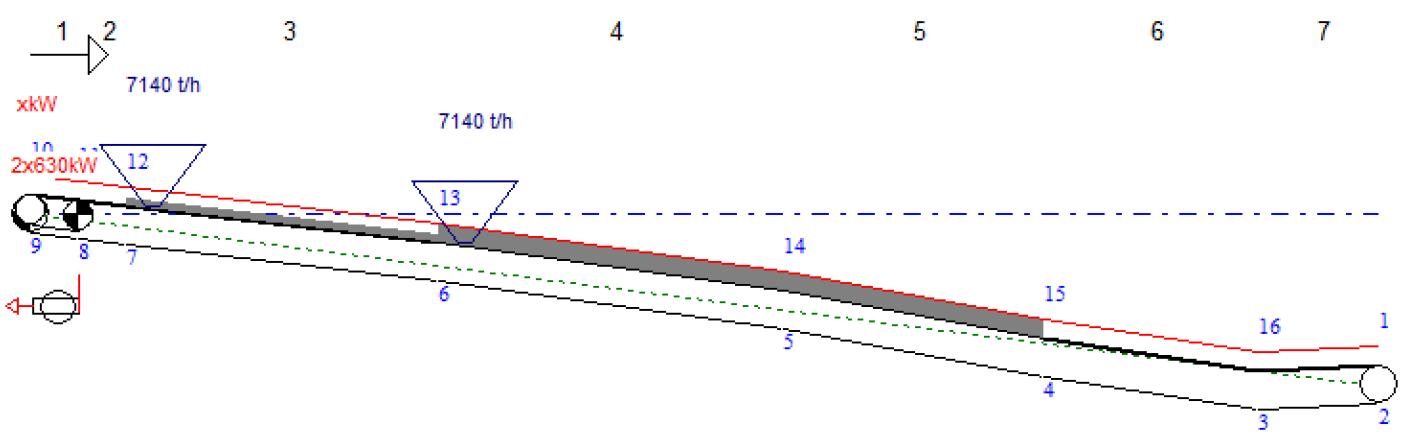

(b)

Figure 6. The profile of the study route of the overburden conveyor, loaded on two subsequent mining levels and being alternatively discharged on its route: (a) 1 mining level below the second loading point, (b) 2 mining levels below the second loading point (source: QNK-TT).

Table 2. Variants of loading the analyzed conveyor on a ramp with an overburden stream from two excavators, A and B, at subsequent mining levels (the conveyor is discharged on its route) and the resulting drive power.

Mode of Loading Overburden on Levels A and B and Its Presumed Share of the Operation Time

\begin{tabular}{|c|c|c|c|c|c|c|c|c|c|c|c|}
\hline \multirow{2}{*}{\multicolumn{2}{|c|}{$\begin{array}{l}\text { Mining Levels Supply } \\
\text { (Volumes, Tonnages) }\end{array}$}} & \multicolumn{10}{|c|}{ Operation Time } \\
\hline & & 1 & 2 & 3 & 4 & 5 & 6 & 7 & 8 & 9 & 10 \\
\hline & & 0.075 & 0.1 & 0.15 & 0.1 & 0.075 & 0.075 & 0.1 & 0.15 & 0.1 & 0.075 \\
\hline \multirow{2}{*}{ A } & $\mathrm{cbm} / \mathrm{h}$ & 4200 & 4200 & 2500 & 3750 & 0 & 4200 & 4200 & 2500 & 3750 & 0 \\
\hline & tonnes $/ \mathrm{h}$ & 7140 & 7140 & 4250 & 6375 & 0 & 7140 & 7140 & 4250 & 6375 & 0 \\
\hline \multirow{2}{*}{ B } & $\mathrm{cbm} / \mathrm{h}$ & 0 & 4200 & 2500 & 3750 & 4200 & 0 & 4200 & 2500 & 3750 & 4200 \\
\hline & tonnes $/ \mathrm{h}$ & 0 & 7140 & 4250 & 6375 & 7140 & 0 & 7140 & 4250 & 6375 & 7140 \\
\hline \multirow{2}{*}{$A+B$} & $\mathrm{cbm} / \mathrm{h}$ & 4200 & 8400 & 5000 & 7500 & 4200 & 4200 & 8400 & 5000 & 7500 & 4200 \\
\hline & tonnes $/ \mathrm{h}$ & 7140 & 14,280 & 8500 & 12,750 & 7140 & 7140 & 14,280 & 8500 & 12,750 & 7140 \\
\hline \multicolumn{2}{|c|}{ Calculated drive power, $\mathrm{kW}$} & -256 & -547 & -251 & -469 & -41 & -569 & -1169 & -623 & -1024 & -354 \\
\hline \multicolumn{2}{|c|}{ potential energy recovery, $\%$} & 33 & 47 & 36 & 45 & 11 & 49 & 60 & 54 & 59 & 46 \\
\hline \multicolumn{2}{|c|}{ Position of the discharge station } & \multicolumn{5}{|c|}{$\begin{array}{c}1 \text { level below the B mining level } \\
(-40 \mathrm{~m} \text { from the level A-see Figure } 5 \mathrm{a})\end{array}$} & \multicolumn{5}{|c|}{$\begin{array}{l}2 \text { levels below the B mining level } \\
(-60 \mathrm{~m} \text { from level A-see Figure } 5 \mathrm{~b})\end{array}$} \\
\hline
\end{tabular}

The actual removal plan can be easily applied to provide more accurate estimations of electric energy generated on the transportation ramp. If there is a decision to relocate vol- 
umes of overburden from the temporary dumpsite to the bottom of the final pit (Figure 1c), the mine can recover some electric energy after the closure of exploitation.

The cost of implementation of power supply with a regenerative inverter can be estimated to EURO 100 thousand for each drive unit. The large conveyors are usually driven by 2 or 3 drive units that give EUR 200-300 thousand of the investment costs. The rising wholesale energy price in Poland is reaching some EURO 80 per MWh, which means that the investment would pay off in 3-4 years, not to mention the value of obtained "white certificates" of saved energy [3]. After finishing the opportunity of transporting masses of overburden downhill, the regenerative inverter equipment can be easily dismantled and installed on another conveyor because large lignite belt conveyor systems are usually constructed from unified equipment, including their drive units.

Producing "green" energy is also synonymous with reducing energy production from fossil fuels, which, according to KOBIZE [24], is convertible into reducing $\mathrm{CO}_{2}$ emissions and pollutants $[8,24]$. The obtained indicators provide valuable input for energy audits and reports on the reduction in environmental impact by the mine.

\section{Conclusions}

A declined belt conveyor is a mining machine that exploits potential gravitational energy. In a case of a continuous surface lignite mine, depending on the given technology of removing, dumping, and relocating volumes of overburden, it may be possible to recuperate the energy of the overburden transported from the upper mining levels (or from a temporary dumpsite) to the located lower spreader on the dumping level. Depending on the actual mine layout and advance, significant amounts of recovered energy can be obtained from the transported overburden massive masses for lignite mines.

Equipping the declined conveyor (operating on a transportation ramp at a distribution point) with the possibility of generator operation with appropriate automation of electricity recovery along with dedicated dispatching management procedures on given overburden levels to keep the energy recovery rate high will allow for the production of "green" electricity. The lignite mine will then become a prosumer of electricity, which has both practical (revenue from sales of energy) and public relations image significance.

According to the analyzed case study, an investment into the installation of regenerative inverters for the electric power supply of the declined overburden conveyor would pay off within 3-4 years.

The conveyor recuperating energy cannot waste its drive power on unnecessary motion resistances caused by worn elements or poor operational conditions. The calculations made in this paper were done for typical belt conveyor layout and equipment but with no allowance for additional wastes of energy. The use of an accurate method of calculating belt conveyor resistance to motion is vital to give the proper assessment of possible energy recovery. It must be noted that the efficiency of conversion of the recovered mechanical energy into the electric one has not been analyzed as it depends on the applied solution of conveyor drive units control equipment.

Lignite surface mining operations are extensive electric energy consumers. Sustainable mining operations require not only to cut all unnecessary energy consumption but also-if possible- to recover the potential gravitational energy from exploited masses of overburden. Even in the phasing out of the lignite mining in Europe, there is still an opportunity to recover energy during the reclamation works of post-mining voids.

Author Contributions: Conceptualization, W.K. and R.K.; Funding acquisition, R.K.; Investigation, W.K.; Methodology, W.K.; Project administration, R.K.; Supervision, R.K.; Validation, R.K.; Writingoriginal draft, W.K.; Writing-review \& editing, W.K. All authors have read and agreed to the published version of the manuscript.

Funding: The research work was cofunded with the research subsidy from the Polish Ministry of Science and Higher Education granted for 2021. 
Data Availability Statement: The details of calculations in the Excel spreadsheet, containing the results from the specialised QNK-TT software for calculations belt conveyors hat are presented in this study are available on request from the corresponding author

Conflicts of Interest: The authors declare no conflict of interest.

\section{References}

1. Clénet, D. Optimising Energy Efficiency of Conveyors; White paper WP20100601EN; Schneider Electric SA: Rue il-Malmaison, France, 2010.

2. He, D.; Pang, Y.; Lodewijks, G. Green operations of belt conveyors by means of speed control. Appl. Energy 2017, 188, 330-341. [CrossRef]

3. Available online: https://www.bialecertyfikaty.com.pl/media/Ustawa_o_efektywnosci_energetycznej.pdf (accessed on 2 July 2021).

4. Available online: https:/ / eur-lex.europa.eu/legal-content/PL/TXT/PDF/?uri=CELEX:32018L2002\&from=EN (accessed on 2 July 2021).

5. Rodríguez, J.; Pontt, J.; Becker, N.; Weinstein, A. Regenerative Drives in the Megawatt Range for High-Performance Downhill Belt Conveyors. IEEE Trans. Ind. Appl. 2002, 38, 203-210. [CrossRef]

6. Available online: http:// conveyor-dynamics.com/index.php/project/los-pelambres/ (accessed on 2 July 2021).

7. Available online: https://iran.phoenix-conveyorbelts.com/pages/extreme-conveyor-belt/strength/strength_en.html (accessed on 2 July 2021).

8. Gladysiewicz, L.; Kawalec, W.; Król, R. Przenośnik taśmowy jako maszyna górnicza urabiająca energię. (Belt conveyor as a mining machine exploiting energy). Transp. Przemystowy Masz. Robocze. 2019, 4, 5-11. (In Polish)

9. Kawalec, W.; Król, R.; Suchorab, N. Regenerative Belt Conveyor versus Haul Truck-Based Transport: Polish Open-Pit Mines Facing Sustainable Development Challenges. Sustainability 2020, 12, 9215. [CrossRef]

10. Nielsen, K. Sterilization of mineral resources by area planning and urban sprawl. In Proceedings of the International Conference on Mine Planning and Equipment Selection, Wroclaw, Poland, 1-3 September 2004.

11. European Commission. The European Green Deal. Available online: https://ec.europa.eu/info/sites/info/files/europeangreen-deal-communication_en.pdf (accessed on 19 May 2021).

12. Dias, P.A.; Kanellopoulos, K.; Medarac, H.; Kapetaki, Z.; Miranda-Barbosa, E.; Shortall, R.; Czako, V.; Telsnig, T.; Vazquez-Hernandez, C.; Arántegui, R.L.; et al. EU Coal Regions: Opportunities and Challenges Ahead, Joint Research Centre (of the European Commission's) Science and Policy Report; Publications Office of the EU: Luxembourg, 2018. [CrossRef]

13. Kulinowski, P.; Panek, P.; Rubacha, P. Aktualne kierunki poszukiwania energooszczędnych rozwiązań w konstrukcji i eksploatacji przenośników taśmowych (Current directions of seeking the energy-saving solutions of design and use of belt conveyors). Transp. Przemysłowy Masz. Robocze. 2013, 3, 7-12. (In Polish)

14. Roumpos, C.; Partsinevelos, P.; Agioutantis, Z.; Makantasis, K.; Vlachou, A. The optimal location of the distribution point of the belt conveyor system in continuous surface mining operations. Simul. Mod. Pract. Theory 2014, 47, 19-27. [CrossRef]

15. Wozniak, J.; Pactwa, K. Responsible Mining-The Impact of the Mining Industry in Poland on the Quality of Atmospheric Air. Sustainability 2018, 10, 1184. [CrossRef]

16. Stoll, R.D.; ·Niemann-Delius, C.; Drebenstedt, C.; ·Müllensiefen, K. Der Braunkohlentagebau Bedeutung, Planung, Betrieb, Technik, Umwelt; Springer: Berlin/Heidelberg, Germany, 2009. [CrossRef]

17. Gładysiewicz, L. Belt conveyors. In Theory and Calculations; Wroclaw University of Technology Publishing House: Wrocław, Poland, 2003. (In Polish)

18. Jurdziak, L.; Błażej, R.; Bajda, M. Cyfrowa rewolucja w taśmach przenośnikowych-Taśma przenośnikowa 4.0. (Digital revolution in the field of conveyor belts-Conveyor belt 4.0). Transp. Przemysłowy Masz. Robocze. 2018, 2, 6-18. (In Polish)

19. Gladysiewicz, L.; Hardygóra, M.; Kawalec, W. Determining belt resistance. Bulk Handl. Today 2009, 5, $23-28$.

20. Gladysiewicz, L.; Kawalec, W. Optimised Selection Of A Belt Conveyor Loaded By A BWE. In Proceedings of the 8th International Symposium of Continuous Surface Mining ISCSM, Aachen, Germany, 24-27 September 2006.

21. Jurdziak, L. Methodology of BWE efficiency analysis for power reduction of conveyor drives. In Proceedings of the 8th International Symposium Continuous Surface Mining, Aachen, Germany, 24-27 September 2006.

22. Król, R.; Gladysiewicz, L.; Kaszuba, D.; Kisielewski, W. New Quality Standards of Testing Idlers for Highly Effective Belt Conveyors. IOP Conf. Ser. Earth Environ. Sci. 2017, 95, 42055. [CrossRef]

23. Bajda, M.; Hardygóra, M. Laboratory tests of operational durability and energy-efficiency of conveyor belts. IOP Conf. Ser. Earth Environ. Sci. 2019, 261, 12002. [CrossRef]

24. Available online: https://www.kobize.pl/pl/file/wskazniki-emisyjnosci/id/130/wskazniki-emisyjnosci-dla-energiielektrycznej-za-rok-2017-opublikowane-w-grudniu-2018-r (accessed on 2 July 2021). 